\title{
Świadectwo dzienników choroby (XVIII/XIX w.)
}

Elżbieta Wichrowska

TEKSTY DRUGIE 2021, NR 1, S. 117-137

DOI: 10.18318/td.2021.1.7 | ORCID: 0000-0001-7151-6213

\section{Czym był i czym nie był dziennik choroby}

Stale rosnąca, także w Polsce, liczba współczesnych dzienników choroby i ich wydań (m.in. Kofta, Pilch, Stuhr, Tuszyńska) oraz blogów (m.in. Chustka Joanny Sałygi) wpisujących się w nurt współczesnych narracji dotyczących chorób, patografii czy autopatografii, a także prowadzonych badań nad tym typem tekstualizowania choroby' skłania do pytań o początki prywatnego diariusza choroby. Uwagę w tę stronę kieruje i to, co sygnalizuje i oferuje tzw. medycyna narracyjna - otwarcie tradycyjnej medycyny na szeroko rozumiane humanistyczne aspekty choroby ukryte w opowieści pacjenta (traktowanej jako pewien podtyp praktyki autobiograficznej, analizowanej

1 Zob. A.E. Kubiak Inneśmierci. Antropologia umierania iżałoby w późnej nowoczesności, Universitas, Kraków 2014; tejże Dzienniki chorych zmagania z metaforq, w: Ucieleśnienia. Ciało w zwierciadle współczesnej humanistyki, red. A. Wieczorkiewicz, J. Bator, IFiS PAN, Warszawa 2007; E. Zierkiewicz Patografia jako zjawisko kulturowe i jako narzędzie nadawania znaczeń chorobie przez współczesnych pacjentów, „Teraźniejszość - Człowiek - Edukacja" 2012 nr 1.

\section{Elżbieta Wichrowska}

- prof. dr hab., historyk literatury, edytor, kieruje Pracownią rękopisów i ineditów 1750-1850 na Wydziale Polonistyki UW.

Ostatnio opublikowała: Między powstaniem a emigracja, Rysunkowy "dziennik" Piotra Michałowskiego z roku 1832 (2019, wraz z Janem K. Ostrowskim). W przygotowaniu: Jeszcze żywi czy już zmarli. WokółXIX-wiecznych dokumentacji umierania po listopadowej emigracji oraz rzecz o dziennikach choroby i szkicownikach (XVIII/XIX w.). 
z całym kontekstem kulturowym, społecznym, biograficznym i językowym), ale też, równolegle, humanistyki na medycynę 2 .

Już oba człony nazwy - dziennik choroby jako odmiana dziennika zdrowia ${ }^{3}$ - definiują specyfikę takich zapisów i dość ściśle określają ich formę i tematykę. To ciąg dziennych notatek, obserwacji dotyczących czyjejś choroby, zaburzeń homeostazy. Jego początki jako dokumentu osobistego wiązać trzeba w Polsce z przełomem XVIII i XIX wieku, jednym z ważniejszych momentów w historii polskiej diarystyki. To wówczas ujawnia się zmiana dotycząca zarówno tego, co warte jest zarejestrowania w dziennikach, jak i językowych strategii wyrażania emocji (i potrzeby takiego wyrażania), a więc tego, co chciano w dziennikach tekstualizować, w jaki sposób i po co. To obejmujący całą kulturę europejską zwrot ku prywatności, indywidualności, ku ,ja”, który miał wpływ na karierę szeroko rozumianego osobistego piśmiennictwa, wyraźnego zapotrzebowania na zapiski rejestrujące wydarzenia z życia autora i jego najbliższego kręgu, ukazujące „dużą" historię przez pryzmat mikrohistorii, osobistych wydarzeń i związanych z nimi emocji. Ten proces w naturalny sposób dotyczył także chorób i umierania osób bliskich, postaci z punktu widzenia przestrzeni publicznej nieistotnych, takich jak żony i dzieci, potrzeby rejestracji tych wydarzeń, ważnych wyłącznie z punktu widzenia rodziny.

W czystej postaci głównym (wręcz jedynym) zadaniem dziennika choroby tego okresu, zazwyczaj liczącego od kilku do kilkudziesięciu stron, była codzienna rejestracja stanu zdrowia osoby chorującej, a do jego podstawowych cech należały: 1) monotematyczność i sekwencyjny układ opisów (dotyczących m.in. wyglądu chorej czy chorego, ich czynności fizjologicznych, zmian w stanie psychicznym, diety i apetytu lub jego braku, wizyt lekarza i jego diagnoz, także księdza, etapów terapii i jej skuteczności, informacji o podawanych medykamentach, zabiegach i osobach je wykonujących);2) zamknięcie pola obserwacji do niewielkiej przestrzeni (mieszkanie, pokój); 3) określony moment rozpoczęcia i zakończenia prowadzenia dziennika, związany z nagłym pogorszeniem stanu zdrowia (zagrożenia życia) osoby bliskiej lub zajmującej eksponowane stanowisko w hierarchii społecznej, z jej

2 Zob. R. Charon Narrative medicine: honoring the stories of illness, University Press, Oxford 2006; M.J.M Nowaczyk Nasze życie jest opowieścią: czym jest medycyna narracyjna?, „Medycyna Praktyczna" 2014 nr 10; Medycyna narracyjna. Opowieści o doświadczeniu choroby w perspektywie medycznej i humanistycznej, red. M. Chojnacka-Kuraś, WUW, Warszawa 2019. 1647 à l'année 1711, écrit par Vallot, d'Aquin et Fagon tous trois ses Premiers-Médecins [...] par Joseph Adrien Le Roi, Paris 1862. 
wyzdrowieniem lub (częściej) śmiercią; 4) prowadzenie zapisków dotyczących choroby przez najbliższe otoczenie chorego.

Trudno dziś określić zasięg zjawiska na ziemiach polskich, zwłaszcza jeżeli chodzi o prywatne notowania choroby. Dotąd udało się odnaleźć zaledwie kilkanaście prywatnych dzienników z przełomu XVIII i XIX wieku, choć nie ma wątpliwości, że musiało ich być znacznie więcej. Ten archiwalny brak mówi sporo o użytkowym charakterze podobnych zapisków - traktowano je funkcjonalnie i uznawano, że nie ma potrzeby zachowania ich dla kolejnych pokoleń.

\section{Medyk diarystą}

O ile wiek XVII stanowił przełom w rozwoju nauk przyrodniczych, w tym medycznych, z ważną rolą nauczania klinicznego prowadzonego w kilku ośrodkach naukowych w drugiej połowie stulecia, to dopiero wiek XVIII te teoretyczne podstawy wypracowane przez XVII-wiecznych uczonych wykorzystuje w usługach medycznych i prowadzonych terapiach ${ }^{4}$.Zmiany dotyczyć będą nie tylko sposobów leczenia, stosunku do pacjentów, ale też będą mieć wpływ na podejmowane próby popularyzowania wiedzy zdrowotnej, m.in. na temat funkcji organizmu człowieka czy higieny, na dyskusje (głównie na zachodzie Europy) dotyczące np. prawnych oznak zgonu i tzw. śmierci pozornej. Te przemiany długo nie obejmowały polskiej refleksji teoretycznej dotyczącej istoty chorób, o takiej u nas mówić można w zasadzie dopiero od przełomu XVIII i XIX wieku, czego jednym ze świadectw jest pojawienie się właśnie wówczas polskich czasopism o tematyce medycznej oraz stałych rubryk poświęconych problemom zdrowia i chorób w prasie pozamedycznej, np. w „Izis polska”, piśmie o profilu naukowo-gospodarczym.

Datowane zapiski na temat stanu chorych wprowadzono dość wcześnie w praktyce szpitalnej ${ }^{6}$. Z biegiem czasu na tablicach nad łóżkami zaczęto

4 M. Nowacka Rozwój medycyny a poziom świadomości zdrowotnej wXVII wieku, „Roczniki Filozoficzne" 2014 t. LXII nr 4, S. 103-104.

5 Zob. Ph. Ariès Człowiek i śmierć, przeł. E. Bąkowska, PIW, Warszawa 1989, s. 387-392. Warto odnotować m.in. prace anatoma J.B. Winslowa, dotyczące śmierci pozornej i „strasznych tortur i rozpaczy ludzi zakopanych żywcem"; por. tegoż Terrible supplice et cruel désespoir des personnes enterrées vivantes [...] 1752

6 Z. Podgórska-Klawe zwraca uwagę na "historie chorób” już z XV wieku; zob. tejże Od hospicjum do współczesnego szpitala, rozwój historyczny problematyki szpitalnej w Polsce do końca XIX wieku, Zakład Narodowy im. Ossolińskich, Wrocław 1981, s. 204. 
zamieszczać coraz więcej danych dotyczących chorego i przepisanego mu leczenia, które przez cały okres pobytu chorego w szpitalu uzupełniano usystematyzowanymi notatkami lekarskimi (także dla celów dydaktycznych).Pod koniec XVIII wieku zaczęto to, co dziś nazywamy historiami chorób"7, coraz częściej ogłaszać drukiem, co także miało wymiar popularyzatorski. Te szczegółowe, odpersonalizowane zapisy, rzeczowo relacjonujące stan chorych, pozbawione były pierwiastka emocjonalno-religijnego, który cechował wiele staropolskich wypowiedzi dotyczących chorób, związanych m.in. z literaturą artis bene moriendi czy księgami cudów i łask, gdzie choroba najczęściej ukazywana była w perspektywie eschatologicznej, a temat dolegliwości cielesnych wykorzystywano do pouczeń moralnych i wskazania wiernym konieczności dbania o zbawienie ${ }^{8}$.

\section{Leopold Lafontaine i Jak należy pisać do lekarza o chorobach (1801)}

Ciekawym przykładem zmian, które zaobserwować można w polskiej edukacji i popularyzacji wiedzy medycznej, a także wprowadzenia tego typu notatek w przestrzeń prywatną, była działalność wydawnicza wybitnego lekarza Leopolda Lafontaine'a (1756-1812), chirurga i nadwornego konsyliarza Stanisława Augusta, a potem armii Księstwa Warszawskiego, propagatora szczepienia ospy i organizatora wojskowej służby zdrowia. W latach 1801-1802 Lafontaine zdecydował się na wydawanie własnym sumptem pierwszego polskiego czasopisma medycznego - „Dziennika zdrowia dla wszystkich stanów" - które odegrało ważną rolę w szerzeniu wiedzy na temat zasad higieny i podstawowych wiadomości z „ogólnej medycyny”. Spośród wielu tekstów doktora Lafontaine'a warto tu odnotować pracę, która obok funkcji edukacyjnych mogła mieć pośredni wpływ także na rozwój prywatnych dzienników choroby, myślę o artykule Jak należy pisać do lekarza o chorobach i o sposobie, którego się pacjent ma trzymać, opowiadając mu swoje dolegliwości'.

Niedostatek znajomości własnego ciała wśród pacjentów, tłumaczy Lafontaine,

7 Na ten temat zob. tamże, s. 204-205.

8 Zob. B. Rok Zagadnienie śmierci w czasach nowożytnych - próba postawienia problematyki badawczej i charakterystyka źródeł, "Medycyna Nowożytna” 1994 nr 1/1. S. 37-40; M. Delimata-Proch Choroby w świetle księgi cudów iłask Matki Bożej Świętogórskiej (XVI-XVIII w.), "Kwartalnik Historii Kultury Materialnej" 2018 t. 66 nr 3.

9 "Dziennik zdrowia dla wszystkich stanów” 1801 t. 2 nr 5, s. 167-182. 
a szczególniej każdej z osobna jego części oraz sposobu, w jakim choroby dokładnie opisać należy, jest mi powodem do umieszczenia dla Czytelników moich w „Dzienniku zdrowia” użytecznej w tym względzie tabeli [...]. Każdy więc, chcąc przysłać lekarzowi opisanie własnej lub cudzej choroby, otworzywszy ten „Dziennik”, niech przeczyta uważnie następującą tabelę, a po jej przeczytaniu będzie mógł z większą niż przedtem dokładnością swój raport ułożyć. ${ }^{10}$

Gatunek listu od chorego uprawiali zresztą w XIX wieku sami lekarze, którzy w listach publikowanych w prasie wcielali się w swoich pacjentów lub członków ich rodzin ${ }^{11}$. Listy takie stanowić mogły punkt odniesienia i źródło języka opisu dla prywatnego notowania chorób, ale też oswajały z tekstualizowaniem cielesności, z różnymi aspektami fizjologii organizmu ludzkiego.

Lafontaine przeprowadził klasyfikację potrzebnych medykowi informacji dotyczących stanu chorego i objawów choroby, na które należy zwrócić uwagę w liście do lekarza. Obejmują one dane dotyczące stanu zdrowia sprzed choroby, a także szczegółowe informacje na temat „teraźniejszej choroby”, jej „powszechnych symptomów”, w tym fizycznych, takich jak:

zawrot, kurcze, ból głowy, pragnienie, dreszcz, zimno, gorąco, ubywający, niespokojny pełen marzenia sen, ospałość, skłonność do spania, ubywający lub nadzwyczajny apetyt, gorzki i zepsuty smak, wstręt, osobliwie do zwyczajnych pokarmów, obrzydzenie, womity, biegunki, zatwardzenie, ból w piersiach, w boku, lub spodniej ciała części, bole w plecach $[\ldots]^{12}$.

Oddzielny punkt dotyczy symptomów psychicznych, „stanu umysłu”, świadomości, ,osobliwie” wszelkich „odmian” w porównaniu z „dawniejszym czasem”, takich jak „nieprzytomność, natężenie myśli, czyli wola włada ciałem lub nie? Czyli odchody naturalne z przytomnością się odbywają?"13. Ważna jest obserwacja każdej zmiany w chorym, która powinna zostać zarejestrowana w liście: „zmieniona fizjognomia, oczy słabe, tkliwe na światło [...] Język:

10 Tamże, s. 167-168.

11 Na temat takich listów ukazujących się w angielskiej prasie i związanych z działalnością homeopatyczną lekarzy, także polskich, zob. m.in. E. Wichrowska Marianna zŻeglińskich Dembińska. Polskie początki buntu kobiet, Universitas, Kraków 2017, s. 323-330. 
suchy, wilgotny, obłożony, czerwony, biały, napuchły, pęcherzyki [...] Spodnia część ciała: (w różnych sytuacjach) nadęta, twarda, rozciągniona, natężona, rznięcie w niej, wiatry $[. . .]^{114}$.

Lafontaine, podpowiadając tematykę i język opisów, każe potencjalnym autorom listów rejestrować pracę organów, zmysłów, siły, stan umysłu, wygląd skóry, puls, oddech: m.in. „nadzwyczajnie prędki lub powolny, stękający, chrapiący, głęboko z piersi wydobyty, bolesny (miejsce bólu)", odchody naturalne: „Stolec twardy, miękki, rzadki, zafarbowany z pasami krwawemi, ze krwią, z bólem", urynę: „czas odchodu po używaniu pokarmów lub medycyny, mnogość, zatrzymanie, niesposobność zatrzymania, odmiany w stojącej, gęsta, mętna, do końskiej podobna, obłoczki mająca; własność sedymentu"; ciekawią go ponadto: „Transpiracja i poty”; ,wyrzut i ślina”; , krew”; „przyrodzenie (stan naturalny lub chorowity, weneryczne symptomy)"15.

Osobne miejsce zajmują "zapytania względem chorób kobiecych" (podobnie jak dalej dziecięcych), tu bowiem, oprócz wcześniejszych pytań „ogólnych”, pojawiają się też uzupełniające, dotyczące m.in. „miesięcznego odchodu”: "następowanie, czas, porządek, kolor, ostrość, ilość krwi, bolesne odchodzenie, zupełne ustanie, przy jakich symptomach? symptomy ustającego, przez co ustały”, ale też stanu kobiety będącej w ciąży: m.in. „stan przeszłej ciężarności [...] symptomy przy teraźniejszej ciąży: zatwardzenie, obrzydzenie, womity, zatrzymanie uryny, nabrzmiałe nogi, kurcze, stan piersi, spodniej ciała części. Używane lekarstwa, czy puszczano krew, z jakim skutkiem?”, połogu oraz stanu po połogu czy, w oddzielnym punkcie, chorób kobiecych: „biały śluz, upławy i wystąpienie maciczne, kurcze, dolegliwości, które są skutkiem ciężkiego porodzenia lub połogu”16. „Nader przyjemną dla mnie będzie rzeczą - kończy swój wykład Lafontaine - jeżeli pierwszy opis choroby, który od jakiego pacjenta odbiorę, podług podanych przeze mnie znajdę ułożony prawideł"17.

Nie udało się dotąd natrafić na dzienniki pacjentów prowadzone przez Lafontaine ${ }^{18}$.

\footnotetext{
14 Tamże, s. 174.

15 Tamże, s. 175-176.

16 Tamże, s. 176-177.

17 Tamże, s. 182.

18 W zbiorach wileńskich zachowała się bogata kolekcja historii chorób pisanych przez lekarzy wileńskich i z terenu Wielkiego Księstwa Litewskiego z XVIII i I poł. XIX wieku; zob. B. Urbanek Polskie archiwa medyczne w Wilnie, „Medycyna Nowożytna” 1994 nr 1, s. 143-146.
} 
Wiadomo, że inny wybitny warszawski lekarz Walenty Gagatkiewicz miał zwyczaj „zapisywać co dzień wszystko, cokolwiek szczególniejszego względem chorób u swych pacjentów dostrzegł"19. Podobnie Jan Chrzciciel Czempiński, dziad Klementyny z Tańskich Hoffmanowej, , do 1otej [wieczór] zapisywał dziennik chorych swoich”, który „utrzymywał jak najrzetelniej”20. Na Wydziale Lekarskim Królewskiego Uniwersytetu Warszawskiego student w ramach egzaminu, oprócz dysputy, musiał złożyć „rozprawę przez siebie wypracowaną" oraz dziennik chorób przez siebie leczonych w czasie dwuletniej praktyki²1. Prowadzenie dzienników chorób przez polskich medyków na początku XIX wieku było więc już rutyną ${ }^{22}$.

Funkcjonowanie zawodowych (lekarskich) dzienników choroby, próby wprowadzenia do powszechnego obiegu praktyki i norm takich zapisków oraz spopularyzowanie wiedzy na temat chorób miały bezpośredni wpływ na rozwój prywatnego diariusza choroby, na strategie jej tekstualizowania i na medykalizację ciała. Ten związek i zależności ujawnia analiza języka opisu chorób, nazewnictwa stosowanego w dziennikach prywatnych, prowadzonych już na początku wieku XIX, wreszcie explicite podawana informacja o wglądzie w nie lekarza i o aprobowaniu przez niego treści dziennika ${ }^{23}$.

L. de Lafontaine Mowa na pochwałę ś.p. Walentego Gagatkiewicza, Doktora Medycyny, członka Towarzystwa Przyjaciół Nauk w Warszawie, czytana [...] 590 Maja 1805 roku, "Nowy Pamiętnik Warszawski" 1805 t. 19, s. 357. Walenty Gagatkiewicz (1750-1805), nadworny lekarz Stanisława Augusta, współzałożyciel (1789) pierwszej w Warszawie Szkoły Chirurgicznej przy Szpitalu św. Łazarza. W 1791 roku starał się - bezskutecznie - o stworzenie w Warszawie Collegium Medicum. K.W. Wójcicki Cmentarz Powq̨zkowski pod Warszawq, t. 1, S. Orgelbrand, Warszawa 1855, s. 69. Źródła do historii Uniwersytetu Warszawskiego, Dział Wydawniczy UW, Warszawa, 1958, s. 68. Dzienniki tego typu prowadzili też bonifratrzy specjalizujący się w opiece nad chorymi Zob. B. Urbanek Idea opieki nad chorym na ziemiach polskich w latach 1809-1914, Oficyna Wydawnicza Arboretum, Wrocław 2001, s. 30.

Osobną grupę stanowią te prowadzone przez sekretarzy m.in. ks. Czartoryskiego: Hipolita Błotnickiego Codzienne relacje o stanie zdrowia chorego (1835) z wykazami osób składających wizyty (m. in. Mickiewicz, Chopin) oraz 1842. M[iesiq̨c] Lipiec iSierpień, Wrzesień. Historia choroby Księcia z receptami, zaleceniami dra Kajetana Stańskiego; a także Kilka słów o słabości Księcia... (BCzart. sygn. 6167 IV). Późnym śladem tej praktyki w odniesieniu do członków społeczności zakonnej jest Dzienniczek z ostatniej choroby Matki Marceliny Darowskiej (15XI 1910 - 5 I 1911), założycielki zakonu niepokalanek. Prowadzona przez jedną z sióstr rejestracja objawów choroby, ale też stanu ducha Darowskiej przed śmiercią i jej wizji służyć też mogła przyszłej beatyfikacji czy kanonizacji. Por. Rozpamiętuję dni, które minęły i lata poprzednie wspominam. Z pism bł. Marceliny Darowskiej, opr. J. Martynuska, Siostry Niepokalanki, Szymanów 2008, s. 109-140. 


\section{Rodzina i dziennik choroby}

Do tych kilkunastu odnalezionych prywatnych dzienników chorób z przełomu XVIII i XIX wieku należy Journal zdrowia Józi $i^{24} \mathrm{z}$ Morskich Ostrowskiej, prowadzony od około 18 (pierwszy wpis nie jest datowany) do 28 maja 1813 roku w Baden pod Wiedniem - w dniach jej agonii - przez hrabiego Antoniego Jana Ostrowskiego, jej męża. Niemal równolegle, bo w czerwcu 1813 roku, w dwa tygodnie po śmierci żony, Ostrowski rozpoczął drugi dziennik Życie najlepszej żony opisane przez czułego jej matżonka dla kochanych dzieci (jego kontynuacją jest Dziennik moich uczuciów czyli elegia serca ${ }^{25}$ ), stanowiący jak dotąd najwcześniejszy przykład polskiego dziennika intymnego. Zachowała się jeszcze jedna relacja z choroby żony Ostrowskiego, w formie listu, sporządzona zresztą z jego polecenia przez obecną przy śmierci Józefy ciotkę, Mariannę z Ledóchowskich Aleksandrowiczową (1752-1826), wojewodzinę podlaską: Wierne opisanie wszystkich rozmów ukochanej Józi z mna w czasie jej choroby ${ }^{26}$. Te trzy datowane zapisy, powstałe w zbliżonym czasie, prezentują trzy różne perspektywy opisu i zapisu choroby oraz agonii członka rodziny i trzy różne strategie autobiograficzno-diarystyczne: zmedykalizowaną, ukierunkowaną na rejestrację objawów, intymną, pełniącą funkcje terapeutyczne, i ostatnią, Aleksandrowiczowej, będącą zapisem rozmów, słów, gestów; to pamiątka rodzinna, ale i świadectwo umierania dobrej katoliczki, żony, matki i pani domur2.

Pierwszy ze wspomnianych dokumentów, Journal słabości, miał pełnić funkcję rejestracyjno-memoryzacyjną, dokumentować przebieg choroby i etapy leczenia racjonalnie, szczegółowo i bez ujawniania refleksji czy emocji diarysty. O tych ostatnich świadczy tylko dukt pisma Ostrowskiego, potknięcia gramatyczne, literówki, uzupełnienia dat wtłaczanych naprędce między wersy albo ich korekty już po dokonaniu wpisu, pominięcia słów, skreślenia, nadpisania, także niewielkie kleksy i małe plamki rozmazanego atramentu (ślady łez?).

24 Journal zdrowia Józi, poszukiwany przeze mnie od wielu lat, został odnaleziony wśród niezinwentaryzowanych materiałów rodzinnych w Muzeum im. Antoniego Ostrowskiego w Tomaszowie Mazowieckim przez kustoszy Muzeum: Magdalenę Sepkowską, Monikę Troszczyńską-Antosik i dr. Daniela Warzochę, sygn.. MT/ED/H/233.

25 W: E. Wichrowska „Twoja śmierć”. Początki dziennika intymnego w Polsce na przełomie XVIII i XIX wieku, Spectrum Press, Warszawa 2012. 
W pierwszym wpisie, niedatowanym, zapewne z 18 maja, retrospektywnym, Ostrowski wraca do momentu (15 maja), gdy w drodze do wód, do Baden, pojawiły się pierwsze niepokojące objawy: „ból głowy ciąglejszy, mocniejszy, mimo lania zimną wodą głowy nie ustający, czasami zimno czasami gorąco dokuczało, przy tem inne afekcje spazmodyczne"28, i relacjonuje to, co działo się aż do wezwania 18 maja, już w Baden. doktora Carla Schenka $(1765-1830)^{29}$, który zajmować się będzie Józefą w ostatnich dniach jej życia. Ten pierwszy wpis stanowi formę medycznego wprowadzenia do jej stanu sprzed wystąpienia ostrych objawów:

Ostatni period był zaczęty na dniu $27 \mathrm{~m}$ a r c a , skończył się $3 g o \mathrm{k}$ w i e t n i a , następujący powinien był przyjść w 3. tygodniu, to jest 25 . kwietnia, a gdy nie nastąpił po dziś dzień, period jest przetrzymywany 3 tygodnie i dni 3. To daje supozycją nowej ciąży, tem bardziej, gdy od trzech tygodni wróciły się bóle głowy w tym stanie zwyczajne, czasami nudność, słabość w nogach i po większej części niesmak do gardła. Po ostatni [m] zwłaszcza periodzie biały odchód bywał znaczny, temu zapobiegał Beryer smarowaniem nóg spirytusem, przemywaniem dolnych części miksturą ut Litt [puste miejsce] i braniem żelaza z cynamonem w proszku ut Litt [puste miejsce] Taki był stan zdrowia do 14 maja z małemi przemianami [k.1r].

Kolejne wpisy pochodzą z 19 maja („10 rano”), 20 maja („5 wieczór”), 22 maja („5 wieczór”), 23 maja („5 wieczór”), 24 maja 1813 („wpół do 9 wieczór”), 25 maja, 26 maja, 27 maja. Ostatni pojawił się pod datą 28 maja, w dniu śmierci Józefy, już po jej zgonie. Dziennik liczy 8 zebranych w poszyt niefoliowanych kart. „Zaszyte” w kilku miejscach litery wskazują, że karty zostały połączone najprawdopodobniej już po dokonaniu ostatniego wpisu.

\section{Dukt pisma}

Dziennik prowadziły dwie osoby. Pierwsze zapiski wyszły spod pióra męża chorej. We wpisie z 24 maja po kilkunastu słowach, w połowie zdania, pojawia się inna ręka (ciotki Aleksandrowiczowej), która przejmuje prowadzenie dziennika. Obserwację tę potwierdza wpis z Życia najlepszej żony, w którym Ostrowski przedstawia strategię prowadzenia dziennika ostatnich chwil Józefy:

28 Journal zdrowia Józi, k. 1 r-v

Także autor prac poświęconych właściwościom źródeł leczniczych w Baden, skutkom kąpieli, diet oraz życiu towarzyskiemu kuracjuszy. 
NB. Journal słabości mojej żony, moją ręką zaczęty, przez P. Aleksandrowiczową przy mnie dokończony i od Szenka doktora aprobowany, wykaże rodzaj i symptoma choroby, a otworzenie ciała, które sama doktorom zaleciła, większe w tej mierze dać się zdaje objaśnienia. ${ }^{30}$

Choć dalsza część wpisu z 24 maja wyszła spod ręki Aleksandrowiczowej, zachowany został rodzaj męski - to ciąg dalszy wypowiedzi męża, który nie miał czasu czy siły na prowadzenie notatek w momencie, gdy Józefa zaczęła stopniowo popadać w obłęd i na jej wyzdrowienie właściwie nie było już nadziei. O tym, co działo się, kiedy Ostrowski zaniechał prowadzenia dziennika, dużo mówi wpis z 25 maja: „Wejrzenie Jej jednak było równie przeraźliwe jak w nocy”.

Journal stabości Józi to maksymalnie zobiektywizowana, zracjonalizowana, zmedykalizowana i odpersonalizowana relacja z dni agonii Józefy z Morskich. Diaryści skupiają się na objawach choroby, rejestrując je zgodnie ze wskazaniami medyków, choćby doktora Lafontaine'a. We wpisach „dziennika słabości" pojawiają się zwykle cztery podstawowe informacje: o stanie fizycznym chorej (m.in. osłabienie, bezsenność, pobudzenie, łaknienie lub jego brak, bóle, parkosyzmy, transpiracja, kolor skóry, pojawiające się plamy), o objawach fizjologicznych (womity, flegma, odchody, w tym krwawe, uryna, pocenie), o stanie psychicznym (wizje, ataki szaleństwa), a także o zaleceniach lekarza, lekach i trybie postępowania. Próbę zobiektywizowania relacji ujawniają choćby odpersonalizowane formy nazewnictwa, tj.,Chora” zjadła, poruszyła się itd. Tylko trzykrotnie, w tym raz w tytule, nazwana została Józią, w dzienniku prowadzonym dwa tygodnie później pojawia się cała gama określeń: Żona, Kochanka, Józia, Anioł.

20 [maj] o 5tej wieczór

Po 5 tej wieczór nastąpiły womity prawie samą flegmą, do gtej brała transpiracja, potem sen nastąpił niestały, nieprzyjemny chorej, aż może do godziny 1wszej w nocy, po przebudzeniu mocny dość był fryzon, a potem zaraz womity, po tych znowu się nieco uspokoiła chora i czasami lubo z niespokojnością drzymała. Ten stan zdrowia z ciągłemi nudnościami trwał do 6tej z rana, poczem znowu przystąpiły fryzony, a po tych gorączka z bólem głowy nieznacznym, lecz nudności ustały. Rano był Doktor przed parkosyzmem i widząc, iż wczorajsze enemy dwie, dzisiejsza ranna jedna, skutku nie zrobiły i wyszły same, zapisał 4 łyżki miksturki [...] Chorej 
doradziłem siąść trochę na łóżku, zwomitowała nieco sobie flegmy z trochą krwi pomieszanej i zdaje się, iż ulgi doznaje [k. 2r.-v. i 3r.].

25 maja

[...] odbywszy spowiedź i przyjąwszy Ś. Kommunią, doznała wiele pociechy i zaspokojenia umysłu i rzekła do mnie, teraz dopiero pewna jestem, że żyć będę. Z równą spokojnością przyjęła pana Schenka. Wejrzenie Jej jednak było równie przeraźliwe, jak w nocy. W godzinę potem z przypadku odsłonienia nogi dostrzegła czerwoną plamę na łydce [...] przeraźliwym głosem krzyknęła: Jestem zgubiona, jestem w gangrenie. Od tego momentu jej umysł zupełnie się pomieszał i w mocnych rzucaniach okropnym głosem krzyczała, iż jest zamienioną w Diabła, że w Boga nie wierzy. Czasem sądziła się być umarłą. I w tym rodzaju najokropniejsze miała myśli, które pomnażając gwałtowne spazmy, tak się silnie rzucała, że Ją cztery mocne Osoby ledwo utrzymać w łóżku mogły [k. 4v]-5r.

\section{6 [korekta z 25] maja}

W początku poranka nikogo już nie poznawała. Miała czerwone brunatne plamy na twarzy, podobny kolor był ust. Rzucania silne pomnożyły się, mówić lub nie chciała, lub nie mogła. Wzrok miała bardzo okropny, uryny odejście od wczoraj wstrzymało się. Brzuch był odęty, twardy [...] O samym południu krew się na chustach podłożonych pod chorą pokazała się, w godzinę powtórnie już więcej. Trzecie chusty uryną były przemokłe, ale wraz i odchodem krwi - spazmy, rzucania się zmniejszać się zaczęły. [...] Wieczorem znacznie była spokojniejszą. Rzucania mniej mocne - w nocy miała obfity bardzo stolec z niezmiernym fetorem to, co z niej wyszło ekstrementów, po czym brzuch stęchł i zmiękniał, czerwoność brunatna z twarzy i ust zmniejszyła się, z pół godziny drzymała. Reszta nocy była bez snu $[\mathrm{k} .5 \mathrm{v}-6 \mathrm{r}]$.

27 [korekta z 28] maja -

[...] mówiła z rana „głowa mi słabnie, myśli mi się dzikie snują", przez dzień potem cały nic nie mówiła, lecz sposobem patrzania okazywała, że zna, rozumie wszystko $[\mathrm{k} .7 \mathrm{r}-\mathrm{v}]^{31}$.

31 Na marginesie wpisu ciotki Aleksandrowiczowej Antoni Ostrowski dodał notatkę: „Nb. Szenik zapewnia, że ciąży nie było i krew miesięczna odchodziła nie z poronienia". 
\# 28 Maja. Dzień naszego nieszczęścia z straty Ukochanej Józi z początkiem Jey wiecznego więc bez końca szczęścia - [k. 8r]

\section{Ku sobie i własnemu cierpieniu - przeżywanie cudzej śmierci}

Dziennik słabości Józi ma za zadanie rejestrować stan chorej - nie to, co przeżywali jej bliscy, nie to, co mówiła, jej myśli, lęki, ale to, że mówiła (albo że już nie miała na to siły) i w jaki sposób (pobudzona, osłabiona). Z innej perspektywy i na innej zasadzie dokonuje się rekonstrukcja etapów jej powolnego odchodzenia w Życiu najlepszej żony. Tu ta relacja podporządkowana została tematycznie, stylistycznie, pod względem szeroko rozumianego języka narracji dziennika intymnego. Choroba i umieranie 26-letniej kobiety ukazane zostały z perspektywy diarysty, autorefleksji dotyczącej własnej psychiki (uczuć, emocji) i fizyczności oszalałego z rozpaczy (i braku) męża, który musi poradzić sobie z dramatem, na jaki nie był przygotowany. Następuje też ważne w stosunku do dziennika choroby przejście od "Ona” (chora) do „Ty” (moja Józia). To sejsmograf uczuć, chwiejności nastrojów, natężenia przeżyć diarysty i w jakimś sensie katalizator tego przeżywania.

O ile skupienie uwagi na ludzkiej fizjologii, ciele nie dziwi w dzienniku choroby, takie, przypomnę, były wskazówki lekarzy, o tyle już kontynuowanie tej perspektywy w Życiu najlepszej żony, nie tylko w kontekście „cudzej” choroby, ale wspólnego życia pary, wskazuje na pewien zwrot dokonujący się w polskiej diarystyce u progu wieku XIX. Opisy kobiecej cielesności, „periodów", ich długości i obfitości, bolesności wykluczającej z życia ${ }^{32}$, przebiegu ciąż pełnych komplikacji i cierpień, karmienia piersią stają się ważnym, niecodziennym elementem męskiej narracji diariuszowej. Wskazują na dokonującą się zmianę w myśleniu i pisaniu o rodzinie, miłości, a przede wszystkim o kobiecie i żonie.

W szczegółowości opisu, odnotowywaniu drobnych odruchów tkwi nowy, dramatyczny, pełen ekspresji sposób relacjonowania cudzej choroby i umierania. Jaki wpływ mógł mieć na to dziennik choroby, który staje się już nie tylko narzędziem lekarzy, ale i elementem życia prywatnego, trudno dziś ocenić, choć równie trudno pominąć fakt, że istniał i oddziaływał.

"Z końcem ciąży, po rozwiązaniu, wprawdzie ustawały zupełnie te bóle, lecz zastępowały osłabienia niezmierne przez zwykłe kobietom periody, które przymuszały leżeć, tak były mocne, iż zawsze $8 \mathrm{dni}$, a czasem więcej trwały i pociągały za sobą spazmy, smutki i inne podobne afekcje. Przy zatrzymanym periodzie, wydarzającym się zwykle do kilku miesięcy po połogu, podobne jak w ciąży bywały bóle głowy", tamże, s. 266. 


\section{Ku cielesności}

Do XIX wieku szeroko rozumiana literatura pamiętnikarska tylko w niewielkim stopniu zwracała uwagę na to, co można by nazwać cielesną przestrzenią ludzkiej egzystencji. Doświadczenie XVI-, XVII- czy nawet jeszcze XVIII-wiecznego polskiego diarysty najczęściej pozbawione było takiej refleksji: nie obejmowało czegoś, co można by nazwać doświadczeniem czy świadomością ciała i jego reakcji. Można tu nawet mówić o redukcji cielesności. „Rewaloryzację” ciała jako niezbywalnego elementu ludzkiej natury przyniósł dopiero - pisał Michał Paweł Markowski - Nietzsche i jego filozofia będąca "krytyką rozumu, odwołującą się do ciała jako do tego, co rozumowi się wymyka, nie tylko po to, by ujawnić ograniczenia samego rozumu, ale też po to, by ukazać podstawy naszego bycia w świecie"33. Ta rewaloryzacja została zresztą określona mianem z w r o tu ci el e s n e g o, który doprowadził do wieloaspektowego ujęcia człowieczeństwa, natury ludzkiej oraz możliwości poznania siebie i świata ${ }^{34}$. Ale pewne symptomy antykartezjańskie, które można by nazwać przedpolem zwrotu cieles nego, dostrzegalne są już wcześniej, pod koniec XVIII wieku, przede wszystkim w filozofii Maine de Birana i jego koncepcji „ciała własnego"35. Ważnym etapem na drodze ku odzyskaniu cielesności wydają się właśnie pojawiające się w diarystyce polskiej u progu XIX wieku dzienniki choroby, nie tylko te prowadzone przez medyków, ale, co istotniejsze, także przez najbliższe otoczenie chorej/chorego (umierającego), męża, ciotki, ojca. Oczywiście epistolografia XVIII-wieczna, a nawet wcześniejsza, pokazuje, że tabuizacja pisania o własnej fizjologii, o obrzmieniach brzucha, wiatrach, rozstrojach, womitach, o lewatywach czy puszczaniu krwi nie dotyczyła korespondencji36. Prywatne XIX-wieczne dzienniki choroby, skupiające uwagę niemal wyłącznie na cielesności i materialności człowieka, jego fizjologii, stanowią ważne świadectwo drogi

rów i Arkadia - 70 lat Muzeum. Księga Pamiq̨tkowa, red. A. Morawińska, Muzeum w Nieborowie i Arkadii, Nieborów, Arkadia 2015. Wiele przykładów podaje B. Popiołek Kobiecy świat w czasach Augusta II. Studia nad mentalnością kobiet z kręgów szlacheckich, Wydawnictwo Naukowe Uniwersytetu Pedagogicznego, Kraków 2003. 
ku samoświadomości ciała i znarratywizowania różnych aspektów świata cielesnego, i to na długo przed wspomnianym wyżej zwrotem cielesnym. To choroba i konieczność jej obserwacji (dyktowana przez medyków) sprawiają, że cielesność, funkcje ciała i fizjologia wychodzą z cienia, stają się ważnym elementem ludzkiej egzystencji, ludzkiego doświadczenia i podlegają obserwacji oraz rejestracji przez diarystów.

Ten wyraźny zwrot ku cielesności i fizjologii sygnalizują też tytuły diariuszy choroby. Przykładem Dziennik fizjologiczny spostrzeżeń w słabości najukochańszego ojca i inne zanotowania [...] spisywane podczas trwającej prawie miesiąc choroby ${ }^{37}$ prowadzony także przez Ostrowskiego w czasie agonii jego ojca, Tomasza, aż do zgonu 5 lutego. Obejmuje on dwadzieścia stron dokonywanych niemal codziennie, o różnych porach dnia i nocy, wpisów dotyczących zmian w zachowaniu, wyglądzie, psychice, ciele i fizjologii ojca autora i jednocześnie prezesa senatu Królestwa Polskiego.

\section{Dziennik choroby Anny Zamoyskiej ${ }^{38}$}

Prowadzony blisko pół wieku później (1859) przez Jana Zamoyskiego (1802-1879) dziennik choroby żony, Anny z Mycielskich, stanowi w pewnym sensie połączenie omówionych wcześniej form zapisu choroby Józefy z Morskich - odpersonalizowanego, zmedykalizowanego dziennika choroby i rejestracji ostatnich rozmów z chorą - z sygnałami refleksji nad własnym stanem psychicznym diarysty. Ma więc charakter użytkowy, jest punktem odniesienia dla działań medyka, ale też formą katalizatora, pełni funkcje psychoterapeutyczne wobec męża, stanowi pamiątkę rodzinną.

Decyzja o prowadzeniu dziennika słabości żony została zapewne podjęta przez Zamoyskiego, gdy pojawiło się zagrożenie dla jej życia. Zachowane wpisy obejmują okres od 4 listopada ${ }^{39}$ (brak pierwszych kart) do 16 grudnia 1859 roku (dwa dni po śmierci żony). Później Zamoyski wielokrotnie będzie podejmował lekturę dziennika, by przy okazji, nawet kilka miesięcy po śmierci żony, wprowadzać datowane uzupełnienia - 26.04.186o i 7.05.186o roku, na ostatniej karcie, ale także w środku, obok uzupełnień czynionych niegdyś na bieżąco, zawsze z lewej, niezapisanej strony karty.

AGAD AOU, sygn. 112.

Archiwum Muzeum Zamoyskich w Kozłówce, sygn. MPK/A/3.

39 Pierwszy datowany wpis, którego data pokrywa się z opisywanymi wydarzeniami, pochodzi z 7 listopada. 
Podobnie jak Journal Józi ten dziennik także służy rejestrowaniu najdrobniejszych szczegółów cielesno-fizjologicznych niedomagań Anny: bolący i twardy język, afty, zgagi, zatwardzenia, rozwolnienia, bóle żołądka, kaszel, duszenie i próby leczenia.

12.11.1859 Ostatni raz perjod miał miejsce w początku września po upadku przypadkiem na schodach i już się nie zjawia od dwóch miesięcy. Nogi nabrzmiałe od około dwóch tygodni [...]-i także od takiegoż czasu język i wnętrze ust jakby w ranach [...]

30.11.59 [...] Około 9tej bardzo narzeka na cierpienia, mówi, że jest bard zo źl e. Miała drugie wypróżnienie rozwolnione (a innych podobno od bardzo dawna nie bywa). [...] Powiedziała też ż e ciągle się obawia asfikcji. „Czy słyszysz ten kaszel? Czy będę miała jeszcze siłę potrzebną do odplucia?

Dziennik, dzięki dacie, czasem dookreślonej godziną zapisu, stanowi użyteczne narzędzie obserwacji procesów zmian w organizmie i psychice chorego nastawionej na rejestrację szczegółu. Zamoyski pilnuje dat, wie, że te w dzienniku, zwłaszcza choroby, mają znaczenie. Pojawiają się u niego w dwóch funkcjach. Pierwsza dotyczy opisywanych wydarzeń, druga związana jest z momentem wpisu, np. .,piszę o 9 1/2 wiecz. 12/12 59 poniedz.”.Zdarza się, że obie, ta dotycząca momentu wpisu i ta wydarzeń, pojawiają się obok siebie. To ciekawy przykład praktyki diarystycznej, świadomości roli daty, ale i wagi bardzo szczegółowego rejestrowania przebiegu choroby.

21.11.59. Rano [...] O 1otej [...] narzekała głównie na ból w języku [...] nie wie, że niestety, te a f t y nie są do zniesienia i koniec bliski zapowiadają! Pulsacji na około 84. Wczoraj podczas dnia było tylko około 80 [...], ale wieczorem do 108. Bardzo osłabiona. Ciagle śpi [...]

Od 1ej znowu drzymie. Narzekała jeszcze na ból w języku. [...] Często powtarza w tych dniach jak dziś: „Pan Bóg jeden wie i ja, ile ja cierpię”.

O zej kazała mi zapalić na kominku i zakryła się kołdrą, choć zwykle narzekała więcej na ciepło jak na zimno [...].

$\mathrm{O}$ зej kazała sobie przyrządzić ryż na bulionie.

O $3^{1 / 2}$ narzeka na boleści wielkie żołądka. Djarja w skutku codeiny już od dawna zmniejszona: były nawet zatwardzenia aż przez dni pięć. [...] Około 11ej wieczór mocny parkosyzm kaszlu, taki że miała wrażenie, że się udusi. [...] Teraz niezmiernie dużo flegmy odrzuca. Powiedziała po tym 
parkosyzmie: „Nie ręczę za siebie, abym nie skonała tej nocy”. Dałem jej trochę Laurier-cerise w rumianku. Przez noc ja czuwałem i Panna Konstancja.

Oboje, Zamoyski i jego żona, mieli świadomość funkcji tego dziennika jako dokumentu medycznego, który ma wspomagać praktykę lekarską: „Kazała mi zapisywać, wiele razy się powtarza w godzinie ta zgaga, aby o tem wiedział Doktor, i dodała że też się to może zdać jako osobliwość dla sztuki lekarskiej. Powtórzyła się ze 4 do 5 razy w godzinie, a każdy raz to ma około 3 do 4 ch minut" 40 .

14 grudnia Zamoyski zapisał: „Skonała w Bogu w środę 14/12 59 o 7 godz. i min. 10. rano". Nieco poniżej dodał kolejną informację: „Piszę dalszy ciąg wspomnień o $11 \mathrm{~min}$. 20 rano 14.12.59" i rozpoczyna relację, niemal godzina po godzinie, z ostatniego dnia życia Anny. Po dwóch dniach przerwy znów siada do dziennika, by ją dokończyć. Oddziela poprzedni wpis, z 14 grudnia, kreską i z boku na marginesie zapisuje: „Piszę 16.12.59 o 2 1⁄2 po południu":

O zej po północy przyszła do mnie Panna Konstancja i powiedziała, że „Pani hrabina prosi Pa hrgo". Na pół rozbudzony, po części nieprzytomny, pośpieszyłem do pokoju Śp. Anny, ale nie dokładnie pamiętam, co się wówczas działo. [...] Gdy się dzieci zeszły, otaczaliśmy łóżko śp. Anny, klęczeliśmy, modliliśmy się i na przemian chwilami siadaliśmy dla zmęczenia. Tak byłem przerażony, że niedobrze już teraz na nowo uobecnić mogę sobie te chwile, które przeciągały się przez 3 godziny, około od 4tej do $7^{1 / 4}$. Było to już konanie, ale nie bardzo ciężkie zdawało się i granie w gardle przy zachowaniu całej podobno przytomności - jakby wielkie zadyszenie. Kilka razy widząc mnie przerażonym albo słysząc płacz w koło siebie, dawała znak ręką, jak żeby powiedzieć, że nie bardzo cierpi, albo mówiła niewyraźnie, ni e, aby nie płakano. [...] Podobno około w pół do 7ej powiedziałem: „Powiedz, duszko: Jezus, Maria, Józef, Wam oddaję duszę moję”. Powtórzyła to niewyraźnie [...]. Po chwili dodała: „J e s z c z e Was błogosławię ..." (To już ostatnie jej słowa.)

Wkrótce potem wpadła zdaje się w stan nieczułości i nastąpiło zupełnie już znaczne konanie, większe granie w piersiach, co trwało do zgonu może około 20 minut. Ostatnie oddechy były powolne, cięższe, przy trzech około usłyszałem jakby zgrzytanie zębów. 
XIX-wieczne relacje agonii, tekstowe i ikonograficzne, wielką rangę nadają momentowi przejścia i temu, jak się ono odbywało, ostatnim decyzjom, gestom, słowom, modlitwom czy rysom twarzy tuż po... Stąd między innymi niebywała kariera w tej epoce motywu l'homme sur son lit de mort ${ }^{41} \mathrm{w}$ rysunkach i zdjęciach oraz pośmiertnych masek. W tę tendencję wpisują się także dzienniki choroby m.in. Anny Zamoyskiej czy tych prowadzonych przez Ostrowskiego, z ostatnimi słowami Józefy: „Ma tête est brouillée e n t i è r e m e n t , si Dieu veut, que je meurs, mon coeur est à lui et à toi, nous nous verrons" (Moja głowa całkiem się wypaliła, jeśli Bóg chce, żebym umarła, powierzam jemu i tobie moje serce, zobaczymy się) ${ }^{42}$.

\section{Wobec śmierci}

Co odsłaniają polskie relacje z choroby i umierania dziecka, żony, ojca, brata z końca XVIII i z XIX wieku? Co zmieniło się w stosunku do analogicznych wypowiedzi epok minionych i jakie relacje zachodzą między tymi prowadzonymi na przełomie XVIII i XIX wieku? Philippe Ariès w Rozważaniach o historii śmierci zauważa, że to właśnie wówczas dokonuje się wyraźna zmiana postawy człowieka wobec śmierci, przemiana wrażliwości: „dawna obojętność stała się nie do przyjęcia i stworzono nowy kult [śmierci], tak popularny i powszechny w okresie romantyzmu, że uznano go za odwieczny"43.

Śmierć uzyskuje wówczas nowy, dramatyczny sens, zwłaszcza w perspektywie śmierci bliskiej osoby, ,"twojej śmierci"44. Ariès zwraca uwagę, że przy pewnych nawiązaniach do dawnych przedstawień funeralnych, obrazów umierającego człowieka, którego łoże otacza rodzina, pojawiają się nowe ważne elementy:

Świadkowie śmierci są poruszeni, wzburzeni, płaczą, modlą się, gestykulują. [...] Rozpacz pozostających przy życiu ma zapewne źródło w nowym zjawisku: rozstanie stało się nie do zniesienia. Wzburzenie ogarnia

41 Na ten temat więcej w przygotowywanej publikacji: E. Wichrowska Jeszcze żywi czy już zmarli... WokółXIX-wiecznych dokumentacji umierania, WUW (Communicare). A. Ostrowski Życie najlepszej żony..., w: E. Wichrowska "Twoja śmierć”, s. 276. Ph. Ariès Rozważania o historii śmierci, przeł. K. Marczewska, Oficyna Naukowa, Warszawa 2007, S. 13. 
jednak ludzi nie tylko u wezgłowia konających czy też na wspomnienie o umarłych. Porusza ich sama myśl o śmierci. ${ }^{45}$

XIX-wieczną żałobę Ariès określa jako histeryczną, bo „żal po utracie bliskich graniczył niekiedy z szaleństwem, jak w pochodzącym z 1893 roku opowiadaniu Marka Twaina The Californian's Tale"46. I jeszcze jedna ważna uwaga Arièsa - obawę budzi nie śmierć własna, lecz cudza - „twoja śmierć”.

Zmiana, o której wspomina Ariès, wiązała się z bardzo wyraźnym już w tym czasie wyodrębnieniem strefy prywatnej w życiu jednostki. Ten proces zaowocował wytworzeniem się nowego typu więzi między członkami rodziny, więzi opartych na nowej uczuciowości i wyrażanej nowym językiem. Znajduje to poświadczenie zarówno w literaturze pięknej, jak i w literaturze dokumentu osobistego. Zwłaszcza cenne w tym wypadku będą ślady epistolograficzne i diariuszowe, a więc takie, które bezpośrednio wiązały się z momentem przeżywania, doświadczania śmierci bliskiej osoby. Nowej stylistyce żalu, ujawniającej się w tekstach dotyczących odchodzenia bliskich, towarzyszy silna potrzeba szczegółowej rejestracji i memoryzacji.

Wszystkie wymieniane przez Arièsa i innych badaczy sygnały zmiany stosunku człowieka przełomu XVIII i XIX wieku do śmierci oraz reakcji na chorobę i utratę bliskiej osoby, łącznie z potrzebą tekstualizowania tych wydarzeń i własnych uczuć, ujawniają dzienniki Ostrowskiego, Zamoyskiego, a także wielu innych, m.in. Adama Jerzego Czartoryskiego czy Adama Konstantego Czartoryskiego, wnuka Izabeli Czartoryskiej i Heleny Radziwiłłowej. Ten ostatni, z roku 1845, łączy cechy obiektywizmu medycznego z wypowiedzią intymną, niepozbawioną fascynacji erotycznej umierającą żoną, Wandą z Radziwiłłów ${ }^{47}$.

Naznaczone silną, momentami „histeryczną” emocjonalnością, poszukują nowych sposobów mówienia o śmierci. Dotyczy to zarówno nowych ujęć, często epatujących fizjologią, co zresztą sygnalizuje już tytuł Dziennika fizjologicznych spostrzeżeń, a potwierdzają opisy, które znaleźć można w Journalu słabości Józi czy dzienniku choroby Anny Zamoyskiej, jak i poszukiwania nowych strategii mówienia o chorobie, śmierci, nowego języka pozwalającego wyrazić przede wszystkim własny ból - cierpienie autorskiego „ja” - co znów ujawnia Pamiętnik wyjazdu nagłego z Florencji i śmierci Leosia, syna Xięcia Ad[ama]

45 Tamże, s. 72.

46 Tamże, s. 78.

47 Na ten temat i innych dzienników choroby więcej w przygotowywanej książce: E. Wichrowska Dziennik choroby i prywatny szkicownik malarski (XVIII/XIX w.). 
Czartoryskiego Wojewody z 1827 roku $^{48}$. 26 października 1827 roku w posiadłości swojej ciotki, Marii Wirtemberskiej, po krótkiej i bardzo gwałtownej chorobie umiera niespełna trzyletni Leoś, drugi syn Adama Jerzego i Anny Sapieżanki" ${ }^{49}$ W godzinę po odejściu Leosia Czartoryski zanotował „W Marynki o godzinie $3 / 4$ pour midi straciłem Leosia mego. [...] Już go nie ma, już go nie znajdziem, nie usłyszym, co moment myśl go szuka i nie znajduje"50. Siedem dni później, już po pogrzebie, Czartoryski wraca do swoich zapisków, w których rozpacz po utracie syna, wypowiedź intymna, łączy się z potrzebą ukazania cielesno-fizjologicznej strony konania dziecka:

Konał przez kilka godzin, grało mu w gar[d]le tak boleśnie, piersi mu nie mogły spełniać swojej powinności [...], lecz go już wzięły konwulsje i drgania nóżąt i rączek, oczy szklane już przytomności nie objawiały, a rączkami wszystko do głowy sięgał i włoski przebierał. I to jeszcze nie oświeciło ślepego doktora, dał mu wina mocnego. Już nie przyszedł do siebie $[. .$.$] Długo się panował biedny, nim uległ.. { }^{51}$

Kończy te zapiski krzyk: „O Boże, o co mi teraz prosić, o co błagać!!!”52.

Te i inne przejmujące opisy umierania bliskich skłaniają do szerszej refleksji nad czymś, co można by nazwać kształtowaniem się nowoczesnego typu uczuciowości funeralnej końca XVIII i pierwszych dziesięcioleci XIX wieku, i nad sposobami zapisu choroby oraz doświadczenia utraty bliskich w polskich dokumentach osobistych, przede wszystkim w diariuszach choroby tego okresu. Znajdą one swoją kontynuację w zapiskach XX-wiecznych, na przykład u Karola Irzykowskiego, który prowadził dziennik choroby córki Basi (1916) od momentu, gdy stało się jasne, że choroba zakończy się śmiercią dziecka. 11 kwietnia notował: „Dziś rano jest gorzej. Śpiączka silniejsza, trochę kaszlu. Spuchnięcie z twarzy nie zmniejsza się, pomimo że bandaż z punkcji rozwinął się i powoli woda wycieka [...]. Rozkład krwi, brak białka, skóra staje się coraz bielszą”. Cztery miesiące później, 3 lipca: „Palce jej są żółtawe, wargi

48 BCzart. rkps 6164, t. 10.

49 Zob. J. Pezda Leon Jerzy - zapomniany syn Adama Jerzego i Anny. Przyczynek do Genealogii Rodu Czartoryskich, „Rocznik Biblioteki Narodowej PAU i PAN w Krakowie” 2004 r. XLIX, s. 168-176. 
w środku napuchnięte [...] ze skóry wznoszą się te same wyziewy, co z kału, który zawsze był trująco smrodliwy"53.

Na przełomie XVIII i XIX wieku dziennik choroby przestaje być wyłącznie pożytecznym instrumentem działalności medyków, a zaczyna odgrywać coraz większą rolę w notatkach osobistych, związanych z prywatną przestrzenią, też chorobą (czasem psychiczną $a^{54}$ ) i umieraniem najbliższych.

Te dzienne zapiski, przypomnę, nie wykraczają poza przestrzeń pokoju, miejsca choroby i odejścia bliskich. Kończą się zawsze w momencie śmierci chorego (lub, rzadziej, wyzdrowienia, jak w przypadku Emilii Woronieckiej ${ }^{55}$ ). Przestrzeń ceremonii pogrzebowych, ważny element staropolskich relacji dotyczących chorób, śmierci, znajduje się już poza polem ich obserwacji.

Silna potrzeba rejestracji choroby lub agonii nie tylko w zapisie dziennikowym, ale też w rysunku profesjonalnego malarza, pracy dagerotypisty, w masce pośmiertnej, obejmuje amatorskie szkice wykonywane przez członków rodziny lub przyjaciół umierającego ${ }^{56}$. W polskiej przestrzeni ikonograficznej takich rejestracji choroby czy, częściej, umierania ojca, siostry, przyjaciela w listach, szkicownikach, na pojedynczych kartkach znaleźć można z pierwszej połowy XIX wieku dużo, a w kolejnych dziesięcioleciach staje się to już „modą”. Rysunki zazwyczaj realizują ten sam motyw - człowiek na łożu śmierci - znany z Chopinowskiego cyklu ręki Kwiatkowskiego. Takie artefakty z momentu agonii zachowały się także w przypadku Antoniego Ostrowskiego (1845): dagerotyp, rysunek Kwiatkowskiego, Piotra Michałowskiego (?) oraz Julii Michałowskiej, córki Ostrowskiego. Rysunek Julii, wykonany na papierze listowym, przedstawia głowę ojca z twarzą jakby zastygłą, z zamkniętymi oczyma, obok niej krzyż. Poniżej rysunku zamieszczono podpis: „Portrait de mon Père fait par ma soeur Julii, à un dernier iuste moment 4 Decembre, 9 3/4 Maderes 1845" (Portret mojego Ojca, zrobiony przez moją siostrę Julię w jego ostatnich chwilach) ${ }^{57}$.

K. Irzykowski Notatkizżycia, obserwacje imotywy, wyb. A. Dobosz, wstęp S. Kisielewski, Czytelnik, Warszawa 1964, s. 161 oraz 174.

54 To przypadek dziennika: Uwagi nad zdrowiem mojej żony, Anny Moszyńskiej prowadzonego przez jej męża Piotra od 13 listopada 1850 do 27 marca 1851 roku. Na ten temat w przygotowywanej książce: E. Wichrowska Dziennik choroby i prywatny szkicownik malarski (XVIII/XIXW.). AP w Lublinie, sygn. 357: Opis okropnej choroby mojej siostry Eleonory Woronieckiej (1829). Na ten temat więcej w przygotowywanej książce: E. Wichrowska Jeszcze żywi czy już zmarli.. WokółXIX-wiecznych dokumentacji umierania. 
Spojrzenie na współczesne dzienniki choroby z perspektywy praktyki prowadzenia diariuszy sprzed blisko 200 lat pokazuje szereg zmian, które dokonały się w pisaniu o chorobie, drogę formowania się refleksji, terminów, stylu i tematyki dotyczącej kondycji cielesnej, fizycznej i psychicznej człowieka chorego. Zmiany obejmują przesunięcie prowadzonych relacji z „twojej” (niegdyś) na „moją” (współcześnie) chorobę, funkcje dzienników, a także granic między tym, co niegdyś należało do przestrzeni ściśle osobistej, intymnej, a dziś bardzo często staje się fragmentem sceny publicznej poprzez decyzję o upublicznianiu rejestracji, a z nimi własnego cierpienia, lęku, cielesności i fizjologii przez chorego-diarystę. To zresztą szersza tendencja, która dotyczy także innych sfer życia prywatnego.

I jeszcze jedna zmiana: o ile większość współczesnych dzienników umierania wychodzi spod piór kobiet, o tyle te z początku wieku XIX były zazwyczaj dziełem mężczyzn.

\section{Abstract}

\section{Elżbieta Wichrowska}

UNIVERSITY OFWARSAW

The Testimony of Illness Diaries (Eighteenth/Nineteenth Century)

The appearance of the private illness diary at the turn of the eighteenth and nineteenth century relates to the turn to privacy at that time as well as th progress in the medical sciences, changes in patient care and the popularisation of knowledge of the human body's functions, hygiene, health and illness. Doctors such as Franz Leopold Lafontaine (1801) advice their patients' closest relatives to record the course of the illness day by day, even hour by hour. These records, about a dozen pages long each, testify to the writers' desperate attempt to maintain objectivity while systematically describing changes in the patient's appearance and mental state and making a note of every physiological function until the patient's death. These texts represent an overlooked aspect of the emerging private diary, which presents a strongly medicalised description of the human body.

\section{Keywords}

dziennik choroby, medicine, Leopold Lafontaine, pathography, medicalisation of the body, physiology, body, woman 